\title{
PEMANFAATAN FESES BABI (Sus Sp.) SEBAGAI SUMBER GAS BIO DENGAN PENAMBAHAN AMPAS SAGU (Metroxylon spp.) PADA TARAF RASIO C/N YANG BERBEDA
}

\section{UTILIZATION OF PIG (Sus sp.) FAECES AS A SOURCE OF BIOGAS WITH ADDITION OF SAGO (Metroxylon spp.) RESIDUE AT DIFFERENT LEVELS OF C/N RATIO}

\author{
Daniel Yohanis Seseray ${ }^{1 *}$, Suharjono Triatmojo ${ }^{2}$, dan Ambar Pertiwiningrum ${ }^{2}$ \\ ${ }^{1}$ Jurusan Produksi Ternak, Universitas Negeri Papua, Manokwari, 98314 \\ ${ }^{2}$ Fakultas Peternakan, Universitas Gadjah Mada, Jl. Fauna No. 3, Bulaksumur, Yogyakarta, 55281
}

\section{INTISARI}

Penelitian ini bertujuan untuk mengetahui produksi gas bio dari campuran substrat feses babi dan limbah ampas sagu dengan perlakuan waktu retensi dan taraf rasio $\mathrm{C} / \mathrm{N}$ yang berbeda yang meliputi temperatur digester, volume gas bio, konsentrasi gas metan dan produksi gas metan, nilai $\mathrm{pH}$, dan produksi VFA. Penelitian dilaksanakan selama 3 bulan bertempat di Desa Sidomulyo, Yogyakarta. Materi yang digunakan adalah 27 unit digester dengan substrat campuran feses babi, ampas sagu, air, dan cairan rumen sebagai inokulum. Data yang diperoleh dianalisis dengan analisis variansi pola split plot dan dilanjutkan dengan uji Duncan's new Multiple Range Test (DMRT) untuk mengetahui perbedaan antara nilai rata-rata. Data volume gas bio, konsentrasi dan produksi gas metan pada perlakuan C/N 20, 25, dan 30 berturut-turut volume gas bio 0,048;0,049;0,043 ml, dan konsentrasi metan 12,14; 11,08; 5,39\%, serta produksi gas metan 0,0058; 0,0055; dan $0,0023 \mathrm{ml}$, ini menunjukkan bahwa produksi gas bio yang dihasilkan tidak optimal karena $\mathrm{pH}$ dan suhu digester juga tidak optimal yaitu rata-rata berkisar antara 5,8-7,0 dan 26,06-29,78 ${ }^{\circ} \mathrm{C}$. Produksi asam lemak volatil (asam asetat, propionat dan butirat) meningkat pada waktu retensi hari ke-20 dan menurun hari ke-30, pada taraf rasio C/N 20 produksi lebih tinggi di banding taraf rasio C/N 25 dan C/N 30. Disimpulkan bahwa penambahan ampas sagu pada feses babi sebagai substrat gas bio pada taraf rasio C/N 20 menghasilkan produksi gas bio yang paling baik.

(Kata kunci: Produksi gas bio, Feses babi, Ampas sagu, rasio C/N)

\section{ABSTRACT}

This study was aimed to determine biogas production resulting from the substrate combination of pig faeces and residue of sago industry at different of level $\mathrm{C} / \mathrm{N}$ rasio. Observed data included temperature of the digester, volume of gas, methane gas concentration and production, $\mathrm{pH}$ value, and volatile fatty acids (VFA) production. The experiment was conducted for 3 months at Sidomulyo village, Yogyakarta. The material used were 27 unit digesters with a substrate of combination of pig faeces, sago residue, water and ruminal fluid as inoculum. Data were analyzed with analysis of variance by split plot pattern followed with Duncan's new Multiple Range Test (DMRT) to determine the difference between the average value. Data biogas volume, methane gas concentration and production at level of C/N ratio of 20, 25 and 30 respectively were 0.048; 0.049; $0.043 \mathrm{ml}$ for biogas volume, 12.14; 11.08; 5.39\% for methane concentration, and 0.0058; 0.0055; $0.0023 \mathrm{ml}$ for methane production, indicated that the processed generated biogas was not optimal because the $\mathrm{pH}$ and temperature of the digester was not also optimal. Average ranged of $\mathrm{pH}$ was from 5.8 to 7.0 and temperature was from 26.06 to $29.78^{\circ} \mathrm{C}$. VFA production (acetic, propionic and butyric) increased in the day $20^{\text {th }}$ and decreased in the day $30^{\text {th }}$, the level of $C / N$ ratio 20 had higher production compared to the $C / N$ ratio 25 and 30. It was concluded that the addition of sago residues on the pig faeces as substrate biogas resulted better biogas production at the level of the C/N ratio of 20.

(Keywords: Biogas production, Pigfaeces, Sago residue, C/N ratio)

\section{Pendahuluan}

Peningkatan permintaan konsumen terhadap bahan bakar minyak di tingkat dunia menyebabkan harga minyak di pasar internasional melambung, hal

\footnotetext{
*Korespondensi (corresponding author):

Telp. +62 85244511534

E-mail: varol.seseray@gmail.com
}

ini sangat mempengaruhi kestabilan harga bahan bakar khususnya di Indonesia. Regulasi pemerintah saat ini di bidang energi adalah dengan tidak menaikkan harga bahan bakar minyak dan melakukan penghematan energi, mengurangi atau membatasi subsidi bahan bakar minyak, memanfaatkan energi alternatif yang baru dan 
terbarukan, serta konversi bahan bakar minyak dengan bahan bakar gas.

Indonesia merupakan salah satu negara yang kaya akan sumber energi terbarukan (renewable energy). Sumber energi terbarukan seperti energi angin, energi matahari, energi air, energi arus dasar laut, dan energi biomassa bahan organik belum termanfaatkan secara optimal. Program pengembangan teknologi renewable energy sebagai solusi alternatif bahan bakar guna menurunkan ketergantungan akan impor bahan bakar minyak, terus dilakukan salah satunya melalui program pengembangan gas bio.

Gas bio merupakan sumber energi terbarukan yang dihasilkan dari fermentasi biomassa bahan organik oleh bakteri metanogen dalam kondisi anaerob. Komposisi gas bio yang dihasilkan bervariasi tergantung jenis bahan isian yang digunakan. Hambali et al. (2007) menyatakan bahwa komposisi kimia gas bio terdiri atas gas metan $\left(\mathrm{CH}_{4}\right)$ 55-75\%, gas karbon dioksida $\left(\mathrm{CO}_{2}\right) 25-45 \%$, nitrogen $\left(\mathrm{N}_{2}\right)$ 0-0,3\%, hidrogen $\left(\mathrm{H}_{2}\right) 1-5 \%$, hidrogen disulfida $\left(\mathrm{H}_{2} \mathrm{~S}\right) \quad 0-3 \%$ dan oksigen $\left(\mathrm{O}_{2}\right) \quad 0,1-0,5 \%$. Gas bio berwarna biru, tidak berbau, dan mudah terbakar. Massa bahan organik yang dapat dimanfaatkan sebagai substrat gas bio antara lain berasal dari limbah pertanian, peternakan, pasar, dan rumah tangga. Limbah peternakan dan limbah pertanian yang cukup potensial sebagai substrat gas bio adalah limbah feses babi dan limbah ampas sagu.

Potensi limbah feses babi cukup besar dilihat dari data populasi ternak babi (Sus sp) di Indonesia hingga tahun 2011 mencapai 7.757 .523 ekor atau mengalami peningkatan sebesar $92,97 \%$ dari tahun 2010 (BPS, 2011). Limbah feses babi merupakan limbah yang dihasilkan dari aktivitas produksi ternak babi selain limbah urine, alas lantai (sekam, jerami, dan serbuk gergaji), sisa pakan dan air cucian kandang (Sihombing, 2006). Limbah feses babi apabila tidak dikelola secara baik dapat mencemari udara, air, dan memicu konflik sosioreligio di dalam masyarakat. Feses babi kaya akan bahan organik terutama unsur nitrogen sehingga dapat digunakan sebagai substrat gas bio.

Sagu (Metroxylon spp.) merupakan tanaman asli Indonesia dengan luas areal sekitar 1,128 juta hektar atau 51,3\% dari luas areal sagu dunia. Proses pengolahan sagu yang dilakukan menghasilkan limbah ikutan berupa kulit batang sekitar 17-25\% dari serat batang, sedangkan ampas sagu $75-83 \%$ (McClatchey et al., 2006). Limbah ampas sagu belum termanfaatkan secara maksimal dan cenderung dibiarkan hingga membusuk di area pengolahan. Ampas sagu yang dibiarkan dapat menimbulkan bau yang tak sedap dan meningkatkan keasaman tanah $(\mathrm{pH}<4)$, yang dapat menghambat pertumbuhan dan menyebabkan kematian tanaman
(Syakir et al., 2009). Ampas sagu banyak mengandung bahan organik terutama unsur karbon yang dapat dimanfaatkan sebagai campuran substrat gas bio (Lay et al., 2010).

Berdasarkan tinjauan di atas terlihat bahwa limbah feses babi dan ampas sagu belum termanfaatkan secara optimal sehingga dapat mencemari lingkungan dan memicu konflik sosioreligio, oleh sebab itu perlu dilakukan penelitian untuk mengetahui produksi gas bio dari campuran limbah feses babi dan ampas sagu. Diharapkan melalui penelitian ini dapat memberikan solusi dalam memanfaatkan feses babi dan ampas sagu menjadi gas bio sebagai sumber energi alternatif dan mengurangi resiko pencemaran lingkungan.

\section{Materi dan Metode}

\section{Materi penelitian}

Bahan yang digunakan adalah feses babi, ampas sagu, air, dan cairan rumen. Feses babi diperoleh dari kandang peternak babi di Kadipiro II, J1. Wates, Yogyakarta. Ampas sagu diperoleh dari hasil ikutan pengolahan sagu secara tradisional di Desa Sabron Yaru, Kecamatan Sentani Timur, Kabupaten Jayapura. Cairan rumen sebagai inokulum diperoleh dari Rumah Potong Hewan (RPH) Giwangan, Kota Yogyakarta.

Alat yang digunakan adalah oven merek Memmert dengan kepekaan $5^{\circ} \mathrm{C}$ dan suhu maksimal $120^{\circ} \mathrm{C}$, desikator, krus porselin $30 \mathrm{ml}$ dan timbangan analitik merek Sartorius dengan kepekaan $0,1 \mathrm{mg}$, labu takar $100 \mathrm{ml}$, pipet $5 \mathrm{ml}$, tabung, spektrofotometer dan blok digestion (Kjeldahl), stirrer, alat destilasi, labu didih $250 \mathrm{ml}$, instalasi gas bio berupa minidigester tipe batch kapasitas 2,8 liter, selang diameter $0,36 \mathrm{~cm}$, ember kapasitas 5 liter, gelas ukur kapasitas $1000 \mathrm{ml}$ dan $50 \mathrm{ml}$, termos, termometer batang air raksa $100^{\circ} \mathrm{C}$ dengan kepekaan $0,5^{\circ} \mathrm{C}$ dan suhu maksimal $110^{\circ} \mathrm{C}$, kertas indikator $\mathrm{pH}$ 0-14 produk Merck, botol sampel, sentrifuse, syringe, vaccumtainer, gas kromatografi merek Hitachi, kolom dari karbon aktif panjang $1 \mathrm{~m}$ diameter $0,5 \mathrm{~cm}$, flame ionisasi detector, penguat signal amplifier dan recorder integrator C.RGA dan alat-alat gelas.

\section{Metode penelitian}

Penelitian ini dilaksanakan pada bulan Februari sampai Maret 2012. Model rancangan penelitian yang digunakan adalah rancangan petak terbagi (split plot design). Campuran feses babi dan ampas sagu dengan perlakuan waktu retensi hari ke10, ke-20 dan ke-30 sebagai petak utama (mainplot) dan taraf rasio $\mathrm{C} / \mathrm{N} 20, \mathrm{C} / \mathrm{N} 25$, dan $\mathrm{C} / \mathrm{N} 30$ sebagai anak petak (subplot). 


\section{Preparasi substrat gas bio}

Feses segar babi Yorkshire pada fase finisher dikumpulkan menggunakan ember penampung selama satu hari. Ampas sagu terlebih dahulu dikeringkan hingga kadar air mencapai kurang lebih $60 \%$, kemudian diayak dengan ukuran partikel 0,1 $0,7 \mathrm{~mm}$. Cairan rumen (inokulum) diperoleh melalui proses penyaringan menggunakan kain kasa dan segera dimasukkan ke dalam termos yang sebelumnya telah diisi air panas dengan suhu $38^{\circ} \mathrm{C}$ dan dibuang sehingga permukaan dalam termos bersuhu $38^{\circ} \mathrm{C}$ sesuai kondisi suhu rumen. Komposisi kimia feses babi dan ampas sagu sebelum digunakan sebagai campuran substrat gas bio, terlebih dahulu dianalisis dengan analisis proksimat (Kamal, 1997) dan analisis tanin (Schanderl, 1970) pada sampel ampas sagu. Komposisi campuran substrat disesuaikan dengan perlakuan taraf rasio $\mathrm{C} / \mathrm{N}$.

\section{Produksi gas bio}

Substrat gas bio berupa campuran feses babi dan ampas sagu dicampurkan dengan air yang telah ditambah inokulum cairan rumen, sebelum dimasukkan ke dalam digester, campuran substrat tersebut dihomogenkan dengan cara diremas-remas dan diaduk hingga campuran merata dan menbentuk slurry. Pengisian slurry ke dalam digester dilakukan satu kali selama periode penelitian (tidak secara kontinyu), sebanyak $66,67 \%$ dari volume digester. Digester diletakkan pada ruangan terbuka dengan temperatur lingkungan selama 30 hari.

\section{Pengambilan sampel dan analisis}

Selama produksi gas bio, dilakukan pengamatan volume gas bio yang terbentuk setiap hari. Suhu digester diamati setiap pukul 06.00, 12.00, 18.00, dan 00.00 WIB, pada waktu retensi hari ke-10, ke-20, dan ke-30 sampel gas bio dan digesta diambil untuk analisis konsentrasi gas metan $\left(\mathrm{CH}_{4}\right)$, produksi VFA, dan nilai $\mathrm{pH}$.

Volume gas bio. Volume gas bio yang terbentuk diukur dengan mengamati perubahan volume air pada buret (asumsi: gas bio yang dihasilkan sama dengan perubahan air yang didorong gas dalam selang).

Volume gas dihitung dengan menggunakan rumus:

Keterangan:

$$
\mathrm{V}=\pi \times \mathrm{r}^{2} \times \mathrm{t}
$$

$\mathrm{V}=$ volume gas berbentuk silinder

$\pi \quad=3,14$

$\mathrm{r} \quad=$ jari-jari selang (silinder)

$\mathrm{t} \quad=$ tinggi selang (silinder)

Konsentrasi gas metan. Konsentrasi gas metan dianalisis dengan menggunakan metode Gas Chromatography (McNair dan Bonnelli, 1969).
Preparasi sampel dilakukan dengan menggunakan syringe $10 \mathrm{ml}$ yang disuntikkan ke dalam karet penutup gas dan kemudian segera dimasukkan ke dalam vaccumtainer $10 \mathrm{ml}$ yang sudah dalam keadaan vacum.

Produksi gas metan. Produksi gas metan diperoleh dengan cara menghitung jumlah volume gas bio yang dihasilkan dengan nilai konsentrasi gas metan, sehingga diperoleh perhitungan dengan rumus:

$$
\mathrm{P}=\frac{\mathrm{Y}}{100} \times \mathrm{Z}
$$

Keterangan:

$\mathrm{P}=$ produksi gas metan

$\mathrm{Y}=$ nilai konsentrasi gas metan

$\mathrm{Z} \quad$ = jumlah volume gas bio yang dihasilkan

Nilai derajat keasaman (pH). Nilai $\mathrm{pH}$ diukur menggunakan kertas indikator $\mathrm{pH}$ ( $\mathrm{pH}$ stick) 0-14 produk Merck yang dicelupkan dalam digesta, diangin-anginkan beberapa menit dan diamati nilai $\mathrm{pH}$ sesuai indikator perubahan warna pada indikator.

Produksi volatile fatty acid (VFA). Produksi VFA dianalisis dengan menggunakan metode Gas Chromatography (Bachruddin, 1996). Sampel digesta disentrifuse sehingga diperoleh supernatant. Diambil $2 \mu 1$ supernatan kemudian diinjeksikan ke dalam kolom pada alat Gas Chromatography.

\section{Analisis data}

Data yang dianalisis adalah suhu digester $\left({ }^{\circ} \mathrm{C}\right)$, nilai derajat keasaman $(\mathrm{pH})$, produksi Volatile Fatty Acid (mM), volume gas bio (ml), konsentrasi gas metan (\%) dan produksi gas metan (ml). Data dianalisis dengan analisis variansi pola split plot menggunakan program SAS (2004) versi 9.1.3, dilanjutkan dengan uji Duncan's new Multiple Range Test (DMRT) untuk mengetahui perbedaan antara nilai rata-rata.

\section{Hasil dan Pembahasan}

\section{Komposisi kimia substrat gas bio}

Substrat gas bio berupa feses babi dan ampas sagu, diukur kandungan kimianya menggunakan analisis proksimat (Kamal, 1997) dan analisis tanin dengan metode Folin-Denis (Schanderl, 1970). Hasil pengukuran disajikan pada Tabel 1.

Limbah ampas sagu merupakan limbah pertanian yang dihasilkan dari proses pengolahan industri sagu. Limbah pertanian umumnya kaya akan unsur karbon dibandingkan dengan nitogen, sehingga rasio $\mathrm{C} / \mathrm{N}$-nya relatif lebih tinggi dari limbah feses ternak. Hasil pengukuran kandungan kimia kedua bahan tersebut menunjukkan bahwa 
limbah ampas sagu memiliki rasio $\mathrm{C} / \mathrm{N}$ sebesar 133,88 : 1, jauh lebih tinggi dari rasio $\mathrm{C} / \mathrm{N}$ feses babi 18 : 1 (Junus, 1987).

Ampas sagu mengandung protein kasar yang lebih rendah dan serat kasar yang lebih tinggi dibandingkan feses babi. Ampas sagu banyak mengandung unsur karbon (C) dan rendah akan kadar tanin sehingga berpotensi sebagai sumber energi atau nutrient bagi perkembangan mikrobia dalam proses fermentasi metanogen. Hal ini didukung dengan hasil penelitian Lay et al. (2010) yang menyatakan bahwa nilai rasio $\mathrm{C} / \mathrm{N}$ ampas sagu sebesar 109 dan dapat dimanfaatkan sebagai campuran substrat gas bio berbahan dasar kotoran sapi. Hasil analisis menunjukkan bahwa feses babi masih mengandung protein kasar yang cukup tinggi dengan nilai kecernaan $72,60 \%$ dan serat kasar yang cukup tinggi dengan nilai kecernaan 3,79\% dari pakan konsentrat yang dikonsumsi.

Komposisi slurry terdiri dari campuran substrat feses babi, ampas sagu, air dan cairan rumen sebagai inokulum pada taraf rasio $\mathrm{C} / \mathrm{N}$ yang berbeda disajikan pada Tabel 2 .

Penambahan limbah ampas sagu sebanyak $3 \%$ dan 5\% pada feses babi sudah mendekati imbangan rasio $\mathrm{C} / \mathrm{N}$ yang optimal kecuali pada penambahan ampas sagu $1 \%$, dimana imbangan rasio $\mathrm{C} / \mathrm{N}$ yang optimal dalam proses produksi gas bio adalah berkisar antara 25 hingga 30 (Triatmojo, 2004 dan UNEP, 1981). Penggunaan ampas sagu sebagai bahan campuran masih sangat sedikit karena ampas sagu memiliki nilai rasio $\mathrm{C} / \mathrm{N}$ yang sangat tinggi, sedangkan feses babi memiliki nilai rasio $\mathrm{C} / \mathrm{N}$ yang rendah sehingga penggunaannya lebih banyak.

\section{Suhu digester $\left({ }^{\circ} \mathrm{C}\right)$}

Hasil pengamatan suhu udara lebih rendah pada pukul 06.00 yaitu antara $24-30^{\circ} \mathrm{C}$ dengan ratarata $26,16^{\circ} \mathrm{C}$, pada pukul 12.00 suhu udara meningkat antara $27-35^{\circ} \mathrm{C}$ dengan rata-rata $31,72^{\circ} \mathrm{C}$ selanjutnya suhu udara menurun pada pukul 18.00 dan 00.00 yaitu antara $25-30^{\circ} \mathrm{C}$ dan $25-29^{\circ} \mathrm{C}$ dengan rata-rata $28,06^{\circ} \mathrm{C}$ dan $26,84^{\circ} \mathrm{C}$. Rata-rata suhu udara dan digester berdasarkan perlakuan taraf rasio $\mathrm{C} / \mathrm{N}$ selama periode penelitian disajikan pada Gambar 1.

Suhu merupakan faktor penting dalam aktivitas mikroorganisme pada proses biologis secara anaerob. Data yang diperoleh menunjukkan bahwa rata-rata suhu digester pada hari ke-9 lebih tinggi dan cenderung mengalami penurunan pada hari ke-13 dan ke-25. Suhu digester mengalami fluktuasi yang disebabkan karena pada proses dekomposisi bahan organik menghasilkan air yang dapat menurunkan suhu digester. Tingginya ratarata suhu pada hari ke-0 hingga hari ke-9 disebabkan proses dekomposisi bahan organik bersifat eksogenik. Peningkatan suhu menunjukkan telah terjadi proses dekomposisi bahan organik, yang akan menghasilkan gas metan, karbondioksida, sejumlah gas lainnya, dan panas. Selain itu karena digester diletakkan di tempat terbuka,

Tabel 1. Komposisi kimia feses babi dan ampas sagu yang digunakan sebagai bahan isian produksi gas bio (composition of pig faeces and sago industry residues used as biogas production materials)

\begin{tabular}{lccc}
\hline \hline \multirow{2}{*}{ Komposisi (composition) } & \multicolumn{3}{c}{ Persentase berdasarkan bahan segar (\%) } \\
\cline { 2 - 4 } & Feses babi (pigfaeces) & $\begin{array}{c}\text { Pakan konsentrat (consentrat } \\
\text { feed) }\end{array}$ & $\begin{array}{c}\text { Ampas sagu } \\
\text { (sago residues) }\end{array}$ \\
\hline Bahan kering (dry matter) & 31,80 & 89,89 & 32,03 \\
Kadar air (moisture) & 68,20 & 10,11 & 67,97 \\
Abu (ash) & 7,14 & 7,63 & 6,77 \\
Protein kasar (crude protein) & 4,27 & 15,58 & 1,87 \\
Lemak kasar (ether extract) & 3,62 & 7,34 & 9,77 \\
Serat kasar (crude fiber) & 7,11 & 7,39 & 9,77 \\
Bahan organik (organic matter) & 92,86 & 92,37 & 93,23 \\
Rasio C/N (C/N ratio) & - & - & 133,88 \\
Tanin (tannin) & - & - & 2,43 \\
Karbon (carbon) & - & - & 46,86 \\
\hline
\end{tabular}

Tabel 2. Komposisi slurry dengan level rasio $\mathrm{C} / \mathrm{N}$ yang berbeda (composition of slurry with different levels of $\mathrm{C} / \mathrm{N}$ ratio)

\begin{tabular}{cc}
\hline \hline Level rasio C/N (levels of C/N ratio) & Komposisi slurry (ml) (slurry composition (ml) $)$ \\
\hline 20 & FB $980+$ AS $20+$ A $900+$ I 100 \\
25 & FB $960+$ AS $40+$ A $900+$ I 100 \\
30 & FB $900+$ AS $100+$ A $900+$ I 100 \\
\hline
\end{tabular}




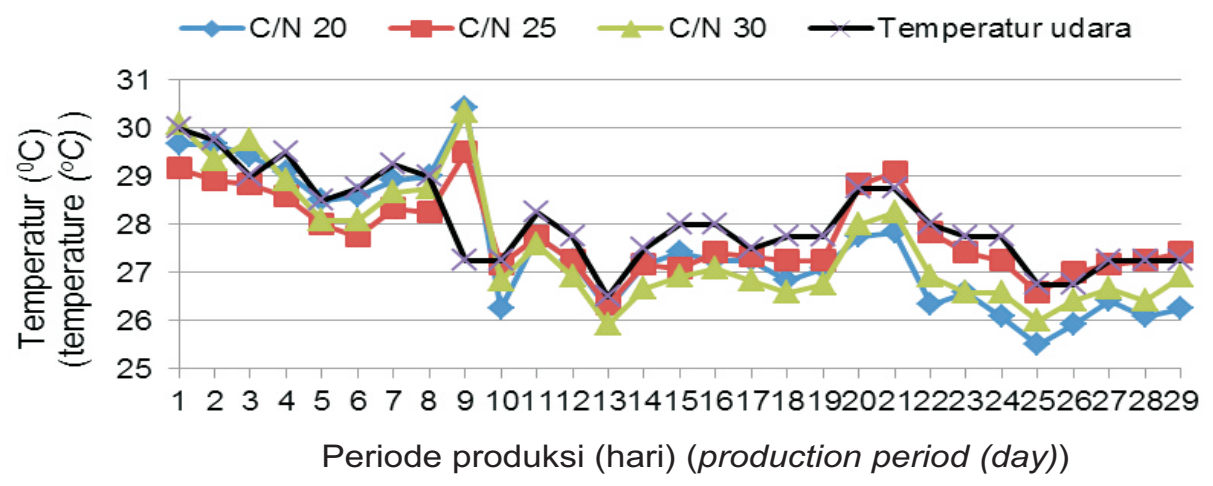

Gambar 1. Rata-rata temperatur udara dan digester selama periode penelitian (the average of air and digester temperatures during the study period).

maka pada malam hari saat suhu udara berada di bawah suhu digester, energi panas yang dihasilkan selama proses fermentasi di dalam digester akan terserap oleh udara secara konduksi. Pada siang hari saat suhu digester lebih rendah dari suhu udara, maka energi panas sinar matahari akan diserap secara radiasi dan konduksi. Kondisi ini menyebabkan suhu gas bio fluktuatif, sehingga proses metanogenesis tidak optimal.

Suhu digester tersebut lebih rendah dibandingkan dengan suhu kerja optimum untuk proses produksi gas bio. Kirby (1983) menyatakan bahwa suhu optimum untuk perkembangan bakteri pada proses pencernaan tinja di dalam digester berkisar antara 30 hingga $35^{\circ} \mathrm{C}$. Patel dan Madamwar (2002), menyatakan bahwa perubahan suhu memiliki kompensasi yang besar terhadap kinerja bakteri anaerob. Suhu optimum untuk pertumbuhan bakteri metanogen dalam digester adalah $37^{\circ} \mathrm{C}$ (mesofilik), namun ternyata digester dapat beroperasi juga pada kondisi psikrofilik dan termofilik.

\section{Volume gas bio}

Rata-rata volume gas bio, konsentrasi, dan produksi gas metan yang dihasilkan pada waktu retensi hari ke-10, 20, dan 30 dengan perlakuan taraf rasio C/N 20, 25, dan 30 tersaji pada Tabel 3.

Hasil analisis variansi perlakuan waktu retensi hari ke-10, 20, dan 30 tidak berbeda nyata terhadap volume gas bio, demikian juga pada taraf rasio $\mathrm{C} / \mathrm{N} 20,25$, dan 30. Hasil analisis variansi menunjukkan bahwa interaksi waktu retensi dan taraf rasio $\mathrm{C} / \mathrm{N}$ yang berbeda tidak memberikan pengaruh yang nyata terhadap volume gas bio $(\mathrm{P}=0,15)$ pada fermentasi dengan substrat campuran feses babi dan ampas sagu.

Meskipun tidak tampak perbedaan yang nyata pada volume gas bio, namun pada waktu retensi hari ke-10 cenderung mengalami peningkatan hingga hari ke-20 dan menurun pada hari ke-30, sedangkan pada taraf rasio $\mathrm{C} / \mathrm{N} 25$ lebih tinggi dibandingkan rasio $\mathrm{C} / \mathrm{N} 20$ dan 30 . Volume gas bio pada hari ke-20 pada taraf rasio C/N 25 adalah tertinggi, akan tetapi di dalam gas bio yang terbentuk tersebut masih terdiri dari berbagai jenis gas. Hal ini menunjukkan bahwa volume gas bio yang tinggi belum tentu mengandung konsentrasi gas metan yang tinggi sehingga perlu dilakukan pengujian terhadap konsentrasi gas metan yang dihasilkan.

\section{Konsentrasi dan produksi gas metan}

Hasil analisis variansi menunjukkan bahwa rata-rata konsentrasi gas metan pada waktu retensi hari ke-10 $(7,48 \%)$ lebih rendah secara nyata dibanding waktu retensi hari ke-20 (10,08\%) dan hari ke-30 (11,06\%), sedangkan pada perlakuan taraf rasio $\mathrm{C} / \mathrm{N} 30(5,39 \%)$ lebih rendah sangat nyata dibanding taraf rasio $\mathrm{C} / \mathrm{N} 20(11,08 \%)$ dan taraf rasio $\mathrm{C} / \mathrm{N} 25$ (12,14\%) (Tabel 3). Rata-rata produksi gas metan pada waktu retensi hari ke-10, 20, dan 30 tidak berbeda nyata, sedangkan rata-rata produksi gas metan pada perlakuan taraf rasio C/N $30(0,006$ $\mathrm{ml})$ lebih rendah sangat nyata dibadingkan dengan perlakuan taraf rasio $\mathrm{C} / \mathrm{N} 20(0,016 \mathrm{ml})$ dan rasio $\mathrm{C} / \mathrm{N} 25(0,017 \mathrm{ml})$. Hasil analisis variansi menunjukkan bahwa interaksi waktu retensi dan taraf rasio $\mathrm{C} / \mathrm{N}$ yang berbeda memberikan pengaruh yang tidak nyata $(\mathrm{P}=0,40)$ terhadap konsentrasi dan produksi gas metan.

Rata-rata konsentrasi gas metan pada perlakuan taraf rasio $\mathrm{C} / \mathrm{N} 20$ dan 30 mengalami peningkatan seiring dengan meningkatnya waktu retensi gas bio, terkecuali pada perlakuan rasio $\mathrm{C} / \mathrm{N}$ 25. Rendahnya konsentrasi gas metan yang dihasilkan, diduga karena kondisi temperatur dan $\mathrm{pH}$ gas bio yang tidak optimal dan rendahnya pemberian inokulum cairan rumen yaitu hanya $0,5 \%$ dari jumlah substrat. Hal ini didukung dengan hasil penelitian Gamayanti et al. (2012) yang menyatakan bahwa penambahan cairan rumen optimal sebagai inokulum adalah $25 \%$ dari jumlah substrat akan meningkatkan kadar gas metan. 
Tabel 3. Volume gas bio, konsentrasi dan produksi gas metan pada waktu retensi hari ke-10, 20, dan 30 dengan taraf rasio $\mathrm{C} / \mathrm{N} 20,25$, dan 30 (biogas volume, concentration and production of methane gas at retention time at 10,20 and $30^{\text {th }}$ day with levels $C / N$ ratio 20,25 and 30 )

\begin{tabular}{|c|c|c|c|c|c|}
\hline \multirow[b]{2}{*}{ Parameter } & \multirow{2}{*}{$\begin{array}{c}\text { Taraf rasio } \mathrm{C} / \mathrm{N} \\
\text { (levels of } C / N \\
\text { ratio) }\end{array}$} & \multicolumn{3}{|c|}{ Waktu retensi (retention time) } & \multirow{2}{*}{$\begin{array}{l}\text { Rata-rata } \\
{\text { (average })^{\mathrm{ns}}}^{\text {a }}\end{array}$} \\
\hline & & $\begin{array}{l}\text { Hari ke-10 } \\
\left(10^{\text {th }} \text { day }\right)\end{array}$ & $\begin{array}{l}\text { Hari ke-20 } \\
\left(20^{\text {th }} \text { day }\right)\end{array}$ & $\begin{array}{l}\text { Hari ke-30 } \\
\left(30^{\text {th }} \text { day }\right)\end{array}$ & \\
\hline \multirow{3}{*}{$\begin{array}{l}\text { Volume gas bio }(\mathrm{ml}) \text { (biogas } \\
\text { volume }(\mathrm{ml}))\end{array}$} & 20 & 0,047 & 0,047 & 0,048 & 0,048 \\
\hline & 25 & 0,050 & 0,054 & 0,043 & 0,049 \\
\hline & 30 & 0,044 & 0,044 & 0,040 & 0,043 \\
\hline Rata-rata (average) ${ }^{\mathrm{ns}}$ & & 0,047 & 0,049 & 0,044 & \\
\hline \multirow{3}{*}{$\begin{array}{l}\text { Konsentrasi gas metan }(\%) \\
(\text { methane gas concentration (\%)) }\end{array}$} & 20 & 11,02 & 11,57 & 13,84 & $12,14^{\mathrm{a}}$ \\
\hline & 25 & 8,30 & 12,64 & 12,31 & $11,08^{\mathrm{a}}$ \\
\hline & 30 & 3,12 & 6,02 & 7,03 & $5,39^{\mathrm{b}}$ \\
\hline Rata-rata (average) & & $7,48^{\mathrm{p}}$ & $10,08^{\mathrm{q}}$ & $11,06^{\mathrm{q}}$ & \\
\hline \multirow{3}{*}{$\begin{array}{l}\text { Produksi gas metan }(\mathrm{ml}) \\
(\text { methane gas production }(\mathrm{ml}))\end{array}$} & 20 & 0,0052 & 0,0055 & 0,0068 & $0,0058^{\mathrm{a}}$ \\
\hline & 25 & 0,0042 & 0,0069 & 0,0053 & $0,0055^{\mathrm{a}}$ \\
\hline & 30 & 0,0014 & 0,0027 & 0,0028 & $0,0023^{b}$ \\
\hline Rata-rata (average) ${ }^{\text {ns }}$ & & 0,0036 & 0,0050 & 0,0050 & \\
\hline
\end{tabular}

$\overline{a, b, c}$ Superskrip yang berbeda pada kolom yang sama menunjukan perbedaan $(\mathrm{P}<0,05)$ (different superscripts at the same column indicate significant differences $(P<0.05))$.

${ }^{\mathrm{p}, \mathrm{q}}$ Superskrip yang berbeda pada baris yang sama menunjukan perbedaan $(\mathrm{P}<0,05)$ (different superscripts at the same row indicate significant differences $(P<0.05))$.

ns Non signifikan (non significant).

Konsentrasi gas metan sangat mempengaruhi produksi gas metan yang terbentuk. Volume gas bio yang dihasilkan cukup tinggi, namun konsentrasi gas metan yang dihasilkan rendah sehingga produksi gas metan yang dihasilkan rendah. Hasil perhitungan menunjukkan bahwa produksi gas metan tertinggi pada taraf rasio C/N 25 hari ke-20 dan rasio $\mathrm{C} / \mathrm{N} 20$ hari ke-30, sedangkan terendah pada perlakuan rasio $\mathrm{C} / \mathrm{N} 30$.

\section{Derajat keasaman (pH)}

Rata-rata $\mathrm{pH}$ digesta gas bio pada taraf rasio $\mathrm{C} / \mathrm{N} 20,25$, dan 30 selama proses penelitian disajikan pada Gambar 2. Rata-rata $\mathrm{pH}$ digesta yang diamati setiap lima hari pada waktu retensi hari ke$10(6,44)$ lebih tinggi tidak nyata dibanding hari ke$30(6,41)$ dan hari ke-20 $(6,33)$, sedangkan pada taraf rasio $\mathrm{C} / \mathrm{N} 25(6,65)$ lebih tinggi secara nyata dibandingkan taraf rasio $\mathrm{C} / \mathrm{N} 30(6,14)$ dan rasio $\mathrm{C} / \mathrm{N} 20$ tidak berbeda dengan rasio $\mathrm{C} / \mathrm{N} 25(6,65)$ dan rasio C/N 30 (Gambar 2). Hasil analisis variansi menunjukkan bahwa interaksi waktu retensi dan taraf rasio $\mathrm{C} / \mathrm{N}$ yang berbeda memberikan pengaruh yang tidak nyata $(\mathrm{P}=0,73)$ terhadap $\mathrm{pH}$ digesta gas bio.

Hasil pengamatan pada setiap digester dengan perlakuan waktu retensi dan taraf rasio $\mathrm{C} / \mathrm{N}$ yang berbeda belum mencapai $\mathrm{pH}$ yang optimal. Kirby (1983) menyatakan bahwa aktivitas bakteri fermentatif mencapai optimal pada suasana $\mathrm{pH}$ netral yaitu 7,0 dan Taiganides (1980) menyatakan bahwa derajat keasaman $(\mathrm{pH})$ optimal untuk proses fermentasi berkisar antar 7 sampai 8, proses tersebut akan terhambat apabila $\mathrm{pH}$ berada pada 6,5 dan berhenti sama sekali pada $\mathrm{pH}$ 5,5. Bakteri-bakteri metanogenik sangat peka terhadap derajat keasaman sehingga pada kondisi $\mathrm{pH}$ yang tidak optimal dapat mempengaruhi produksi gas metan yang dihasilkan.

\section{Asam lemak volatil}

Asam asetat, propionat, dan butirat merupakan jenis asam lemak volatil yang terbentuk pada tahap asidogenesis dan asetogenesis. Timbulnya asam lemak tersebut menunjukkan bahwa sedang terjadi proses asidifikasi dalam proses dekomposisi bahan organik. Proses dekomposisi bahan-bahan organik menjadi bentuk sederhana berupa asam asetat, karbondioksida $\left(\mathrm{CO}_{2}\right)$, dan hidrogen $\left(\mathrm{H}_{2}\right)$ yang digunakan oleh bakteri metanogenik untuk menghasilkan metan dalam proses metanogenesis. Rata-rata produksi VFA pada waktu retensi hari ke-10, 20, dan 30 dengan perlakuan taraf rasio $\mathrm{C} / \mathrm{N} 20,25$, dan 30 masingmasing disajikan pada Tabel 4.

Hasil analisis variansi menunjukkan bahwa interaksi waktu retensi dan taraf rasio $\mathrm{C} / \mathrm{N}$ yang berbeda memberikan pengaruh yang nyata terhadap produksi asam asetat $(\mathrm{P}=0,04)$ hasil fermentasi 


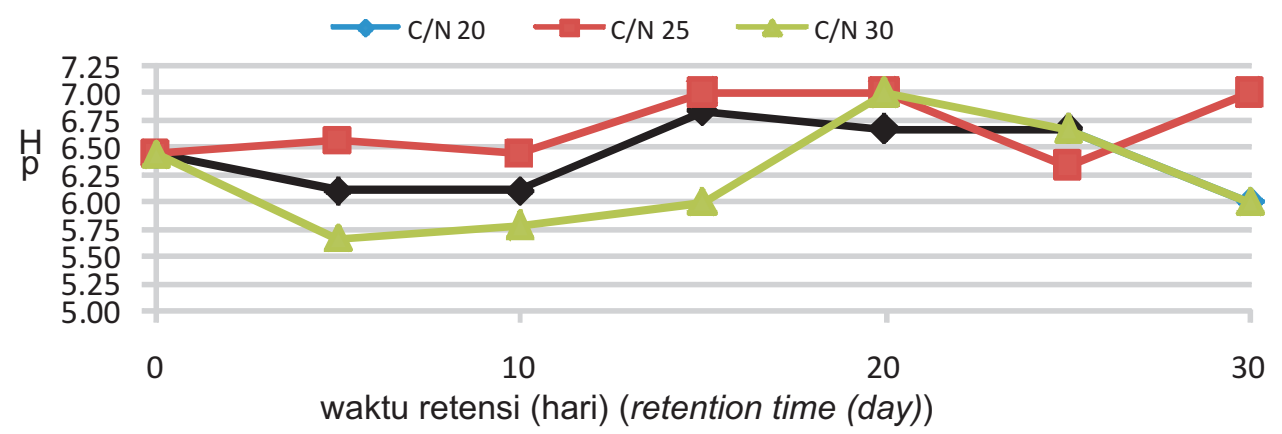

Gambar 2. Rata-rata $\mathrm{pH}$ slurry gas bio (average pH of biogas slurry).

Tabel 4. Produksi VFA (asam asetat, asam butirat, asam propionat) pada waktu retensi hari ke-10, 20, dan 30 dengan perlakuan taraf rasio C/N 20, 25, dan 30 (VFA (acetic acid, butyric acid, propionate acid) production at retention time at 10,20 and $30^{\text {th }}$ day with levels of $C / N$ ratio 20,25 and 30 )

\begin{tabular}{|c|c|c|c|c|c|}
\hline \multirow[b]{2}{*}{ Parameter } & \multirow{2}{*}{$\begin{array}{c}\text { Taraf rasio C/N } \\
\text { (levels of C/N ratio) }\end{array}$} & \multicolumn{3}{|c|}{ Waktu retensi (retention time) } & \multirow{2}{*}{$\begin{array}{l}\text { Rata-rata } \\
\text { (average) }\end{array}$} \\
\hline & & $\begin{array}{l}\text { Hari ke-10 } \\
\left(10^{\text {th }} \text { day }\right)\end{array}$ & $\begin{array}{l}\text { Hari ke-20 } \\
\left(20^{\text {th }} \text { day }\right)\end{array}$ & $\begin{array}{l}\text { Hari ke-30 } \\
\left(30^{\text {th }} \text { day }\right)\end{array}$ & \\
\hline \multirow{3}{*}{$\begin{array}{l}\text { Asam asetat }(\mathrm{mM})(\text { acetic } \\
\text { acid }(m M))\end{array}$} & 20 & 76,02 & 321,91 & 215,80 & $204,58^{\mathrm{a}}$ \\
\hline & 25 & 104,32 & 176,68 & 94,73 & $125,24^{\mathrm{b}}$ \\
\hline & 30 & 92,67 & 229,36 & 45,01 & $122,35^{\mathrm{b}}$ \\
\hline \multirow{4}{*}{$\begin{array}{l}\quad \text { Rata-rata (average) } \\
\text { Asam butirat }(\mathrm{mM})(\text { butyric } \\
\text { acid }(\mathrm{mM}))\end{array}$} & & $91,00^{\mathrm{p}}$ & $242,65^{\mathrm{q}}$ & $118,51^{\mathrm{p}}$ & \\
\hline & 20 & 28,18 & 130,21 & 89,48 & 82,62 \\
\hline & 25 & 45,45 & 135,13 & 32,39 & 70,99 \\
\hline & 30 & 37,39 & 125,05 & 27,65 & 63,36 \\
\hline \multirow{4}{*}{$\begin{array}{l}\quad \text { Rata-rata (average) } \\
\text { Asam propionat }(\mathrm{mM}) \\
\text { (propionate acid }(\mathrm{mM}))\end{array}$} & & $37,0^{p}$ & $130,13^{\mathrm{q}}$ & $49,841^{\mathrm{p}}$ & \\
\hline & 20 & 24,66 & 129,28 & 86,46 & $80,14^{\mathrm{a}}$ \\
\hline & 25 & 48,38 & 134,11 & 33,91 & $72,13^{\mathrm{b}}$ \\
\hline & 30 & 36,53 & 96,21 & 22,69 & $51,81^{\mathrm{c}}$ \\
\hline & $36,52^{\mathrm{p}}$ & $119,87^{\mathrm{q}}$ & $47,67^{\mathrm{p}}$ & \\
\hline $\begin{array}{l}\text { Superskrip yang berbec } \\
\text { he same column indica }\end{array}$ & S & $\begin{array}{l}\text { unjukkar } \\
\text { 05)). }\end{array}$ & daan $(\mathrm{P}<$ & (differen & rscripts \\
\hline $\begin{array}{l}\text { Superskrip yang berbed } \\
\text { the same row indicate } \\
\text { Non signifikan (non sig }\end{array}$ & $\begin{array}{l}\text { yang sama } \\
\text { erences }(P\end{array}$ & ukkan pe & an $(\mathrm{P}<0$ & fferent & cripts at \\
\hline
\end{tabular}

menggunakan substrat campuran feses babi dan ampas sagu. Hasil uji lanjut menunjukkan bahwa rata-rata produksi asam asetat pada waktu retensi hari ke-10 dengan taraf rasio $\mathrm{C} / \mathrm{N} 20$ yaitu 76,01 $\mathrm{mM}$ lebih rendah $(\mathrm{P}<0,05)$ dibanding taraf rasio $\mathrm{C} / \mathrm{N} 25$ dan 30 yaitu masing-masing $94,73 \mathrm{mM}$ dan $92,67 \mathrm{mM}$. Produksi asam asetat pada waktu retensi hari ke-20 dengan taraf rasio C/N 20 yaitu 321,91 $\mathrm{mM}$ secara nyata lebih tinggi dibanding taraf rasio $\mathrm{C} / \mathrm{N} 25$ yaitu 176,68 mM, sedangkan taraf rasio $\mathrm{C} / \mathrm{N}$ 30 yaitu 229,36 mM tidak berbeda dengan taraf rasio $\mathrm{C} / \mathrm{N} 20$ dan 25. Pada waktu retensi hari ke-30 dengan taraf rasio C/N 20 yaitu 215,80 mM lebih tinggi $(\mathrm{P}<0,05)$ dibanding taraf rasio $\mathrm{C} / \mathrm{N} 30$ dan 25 , sedangkan taraf rasio $\mathrm{C} / \mathrm{N} 30$ yaitu $45,01 \mathrm{mM}$ tidak berbeda dengan taraf rasio $\mathrm{C} / \mathrm{N} 25$ yaitu 94,73 $\mathrm{mM}$.
Hasil analisis variansi menunjukkan bahwa interaksi waktu retensi hari ke-10, 20, dan 30 dengan taraf rasio $\mathrm{C} / \mathrm{N} 20,25$, dan 30 memberikan pengaruh yang nyata terhadap produksi asam propionat $(\mathrm{P}=0,02)$ pada fermentasi dengan substrat campuran feses babi dan ampas sagu. Hasil uji lanjut menunjukkan bahwa rata-rata kadar asam propionat pada waktu retensi hari ke-10 dengan taraf rasio C/N 20 yaitu 24,66 mM tidak berbeda dengan taraf rasio $\mathrm{C} / \mathrm{N} 25$ dan 30 yaitu masingmasing 48,38 $\mathrm{mM}$ dan $36,53 \mathrm{mM}$. Pada waktu retensi hari ke-20 dengan taraf rasio C/N 25 (134,11 $\mathrm{mM})$ lebih tinggi secara nyata dibanding taraf rasio C/N $30(96,22 \mathrm{mM})$, sedangkan taraf rasio C/N 20 yaitu $129,28 \mathrm{mM}$ tidak berbeda dengan taraf rasio C/N 30. Pada waktu retensi hari ke-30 dengan taraf rasio $\mathrm{C} / \mathrm{N} 20$ yaitu $86,46 \mathrm{mM}$ secara nyata lebih 
tinggi dibanding dengan taraf rasio C/N 25 dan 30, sedangkan taraf rasio C/N 25 yaitu 33,91 mM tidak berbeda dengan taraf rasio C/N 30 yaitu 22,69 mM.

Rata-rata produksi asam butirat pada perlakuan waktu retensi pada hari ke-20 (130,13 mM) lebih tinggi secara nyata dibanding waktu retensi hari ke-30 $(49,841 \mathrm{mM})$ dan hari ke-10 $(37,0)$, sedangkan pada perlakuan taraf rasio $\mathrm{C} / \mathrm{N} 20,25$, dan 30 tidak berbeda nyata. Hasil analisis variansi menunjukkan bahwa interaksi waktu retensi dan taraf rasio $\mathrm{C} / \mathrm{N}$ yang berbeda memberikan pengaruh yang tidak nyata terhadap produksi asam butirat $(\mathrm{P}=0,21)$ hasil fermentasi menggunakan substrat campuran feses babi dan ampas sagu.

Tabel 4 menunjukkan bahwa produksi VFA mengalami peningkatan pada pengamatan retensi hari ke-20 dan menurun pada hari ke-30. Rata-rata produksi asam asetat, butirat, dan propionat pada perlakuan taraf rasio $\mathrm{C} / \mathrm{N} 20$ lebih tinggi dibanding rasio $\mathrm{C} / \mathrm{N} 25$ dan 30. Substrat sebagai bahan organik yang difermentasi akan menghasilkan VFA, protein mikroba, dan gas. Produktivitas gas yang dihasilkan berkaitan erat dengan produksi VFA dan degradasi bahan organik. Bakteri mengubah bahan organik menjadi VFA disertai dengan terbentuknya gas (Orskov dan Ryle, 1990).

Produksi asam asetat yang dihasilkan lebih tinggi dibandingkan asam propionat dan butirat, karena asam asetat merupakan produk utama dari proses acidogenik menuju pembentukan gas metan. Rendahnya asam propionat dan butirat diduga karena telah dihidrolisis menjadi asam asetat. Ketiga asam lemak volatil tersebut kemudian menurun produksinya pada waktu retensi hari ke30 .

\section{Kesimpulan}

Ampas sagu dapat digunakan sebagai sumber karbon dalam campuran substrat digester untuk menghasilkan gas bio. Volume gas bio dan produksi gas metan lebih tinggi pada waktu retensi hari ke-20 yaitu 0,049 dan $0,015 \mathrm{ml}$ dibanding hari ke-30 dan hari ke-10. Penambahan ampas sagu pada feses babi sebagai substrat gas bio pada taraf rasio C/N 20 menghasilkan konsentrasi dan produksi gas metan yang lebih baik dari taraf rasio C/N 20 dan 30 .

\section{Daftar Pustaka}

Bachruddin, Z. 1996. Aplikasi enzim dalam bioteknologi pertanian. Buletin Peternakan. Edisi khusus: 221-223. Fakultas Peternakan. Universitas Gadjah Mada, Yogyakarta.

Badan Pusat Statistik. 2011. Data Base Direktorat Jenderal Peternakan.
Gamayanti, K.N., A. Pertiwiningrum, dan L.M. Yusiati. 2012. Pengaruh penggunaan limbah cairan rumen dan lumpur gambut sebagai starter dalam proses fermentasi metanogenik. Buletin Peternakan 36(1): 32-39.

Hambali, E., S. Mudjdalipah, H.A. Tambunan, W.A. Pattiwiri, dan R. Hendroko. 2007. Teknologi Bioenergi. Agromedia Pustaka. Jakarta.

Junus, M. 1987. Teknik Membuat dan Memanfaatkan Unit Gas Bio. Penerbit Gadjah Mada University Press, Yogyakarta.

Kamal, M. 1997. Kontrol Kualitas Pakan. Laboratorium Makanan Ternak. Jurusan Nutrisi dan Makanan Ternak. Fakultas Peternakan Universitas Gadjah Mada, Yogyakarta.

Kirby, K.D. 1983. Anaerobic Digester and Its Application to Agriculture Residue Utilization. Australian Government Publishing Service, Canbera.

Lay, A.F. Tondak, dan M. Patrik. 2010. Optimalisasi pengolahan sagu (Metroxylon) menjadi Biofuel. Warta Penelitian dan Pengembangan Tanaman 16 (2): 1-5.

McClatchey, W., H.I. Manner and C.R. Elevitch. 2006. Metroxylon amicarium, M. paulcoxii, M. sagu, M. salomonense, M. vitiense, and M. warburgii (sago palms). Pp 491 - 512 in Traditional Trees of Pacific Islands: their culture, environment, and use. Edited by C.R. Elevitch. Permanent Agricultural Resources, Holualoa, Hawai' $i$.

McNair, H.M. and E.J. Bonnelli. 1969. Basic Gas Chromatography. Consolidated Printers, Berkeley, CA.

Orskov, E.R. and Ryle. 1990. Energy Nutrition In Ruminants. Elsevier Applied Science, London and New York.

Patel, H. and D. Madamwar. 2002. Effects of temperatur and organic loading rates on biomethanation of acidic petrochemical wastewater using an anaerobic ufplow fixedfilm reactor. J. Biortech. 82: 65-71.

SAS (Statistical Analysis System). 2004. SAS Versi 9.1.3. SAS Institute Inc. Cary. NC, USA.

Schanderl, S.H. 1970. In: Method in Food Analysis. Academic Press New York. p. 709.

Sihombing, D.T.H. 2006. Ilmu Ternak Babi. Penerbit Gadjah Mada University Press, Yogyakarta.

Syakir, M., M.H. Bintoro, dan H. Agusta. 2009. Pengaruh ampas sagu dan kompos terhadap produktivitas lada perdu. J. Littri. 15(4): 168173. 
Taiganides, E.P. 1980. Bio Engineering Properties of Feedlot Waste Animal. Applied Science Publisher Ltd, London.

Triatmojo, S. 2004. Penanganan Limbah Peternakan. Jurusan Teknologi Hasil Ternak,
Fakultas Peternakan, Universitas Gadjah Mada, Yogyakarta.

UNEP. 1981. Biogas Fertilizer System. Technical Report on a Training Seminar in China. United Nation Enviroment Program, Nairobi. 